\title{
Micro-endemic and vicariant populations of Opisthacanthus Peters, 1861 (Scorpiones: Hormuridae) in Madagascar, with descriptions of two new species
}

\author{
Микроэндемичные и викариантные попумяџии \\ Opisthacanthus Peters, 1861 (Scorpiones: Hormuridae) \\ с Мадагаскара с описаниями двух новых видов
}

\author{
Wilson R. Lourenço \\ Вильсон Р. Аоуренсо
}

Muséum national d'Histoire naturelle, Département Systématique et Evolution, UMR7205, CP 053, 57 rue Cuvier, 75005 Paris, France. Email: arachne@mnhn.fr

KEY WORDS: scorpion, new species, Opisthacanthus, Hormuridae, micro-endemism, vicariance, Madagascar.

КЛЮЧЕВЫЕ СЛОВА: скорпион, новый вид, Opisthacanthus, Hormuridae, микроэндемизм, викариат, Мадагаскар.

ABSTRACT. Two new scorpion species, Opisthacanthus antsiranana sp.n. and $O$. ambanja sp.n., are described from the North of Madagascar. The new species clearly suggest cases of micro-endemic and vicariant populations within the island. The total number of species of the genus in Madagascar is now elevated to 10 and its known geographical distribution within the island is expanded.

РЕЗЮМЕ. С севера Мадагаскара описаны два новых вида скорпионов, Opisthacanthus antsiranana sp.n. и $O$. ambanja sp.n. Новые виды определенно предполагают случаи микроэндемичных и викариантных популяций на острове. Общее число видов рода на Мадагаскаре возросло до 10, а его известный ареал на острове расширен.

\section{Introduction}

As outlined recently [Lourenço, 2014a, b; Lourenço, Goodman, 2008], Madagascar represents one of the globe's hotspots of biodiversity [see Vachon, 1953; Paulian, 1961; Lourenço, 1996; Goodman, Benstead, 2003]. Studies on the island's scorpions started in the first half of the $19^{\text {th }}$ century and advanced rapidly since 1890 [see Lourenço, Goodman, 2008]. However, it was only by the mid-1990's that the study of the Malagasy scorpion fauna showed substantial progress associated with the description of several new taxa [e.g. Lourenço, 1996, 2003]. Since the early 1990s, intensive field inventory programmes have resulted in extensive new collections covering diverse ecosystems of the island and using a variety of field collecting techniques (e.g. pit-fall traps, Winkler extraction or detec- tion with ultra-violet light). These new specimens have allowed for studies on the distribution patterns, taxonomy, diversity and endemicity of Malagasy scorpions to be evaluated in a new light, Starting from 1995, the number of recognized scorpion taxa on Madagascar has increased by more than 400\% [Lourenço, 2003, 2014a, b].

Certain areas in Madagascar show particularly high levels of diversity and endemism, such as the extreme North of the Island. This is presumably correlated with the presence of unique habitats and a complex geological history, with numerous cases of vicariant events associated with climatic change, volcanism, etc. [Brenon, 1972; Wilmé et al., 2006].

The present study of further collections of hormurid scorpions of the genus Opisthacanthus Peters, 1861, subgenus Monodopisthacanthus Lourenço, 2001, from Madagascar has resulted in the discovery of two new species. These were collected from the extreme North and North-West of Madagascar, and are related to other species known from the North-East or even the extreme South of the island. This pattern of distribution clearly suggests cases of micro-endemism and vicariance among the populations of Malagasy Opisthacanthus.

\section{Material and methods}

The holotypes and four paratypes are deposited in the Muséum National d'Histoire Naturelle, Paris. Three paratypes are donated to the Zoological Museum, Moscow State University, Russia. Scorpions were collected during the night with the help of ultra-violet light. Illustrations and measurements were made with the aid 

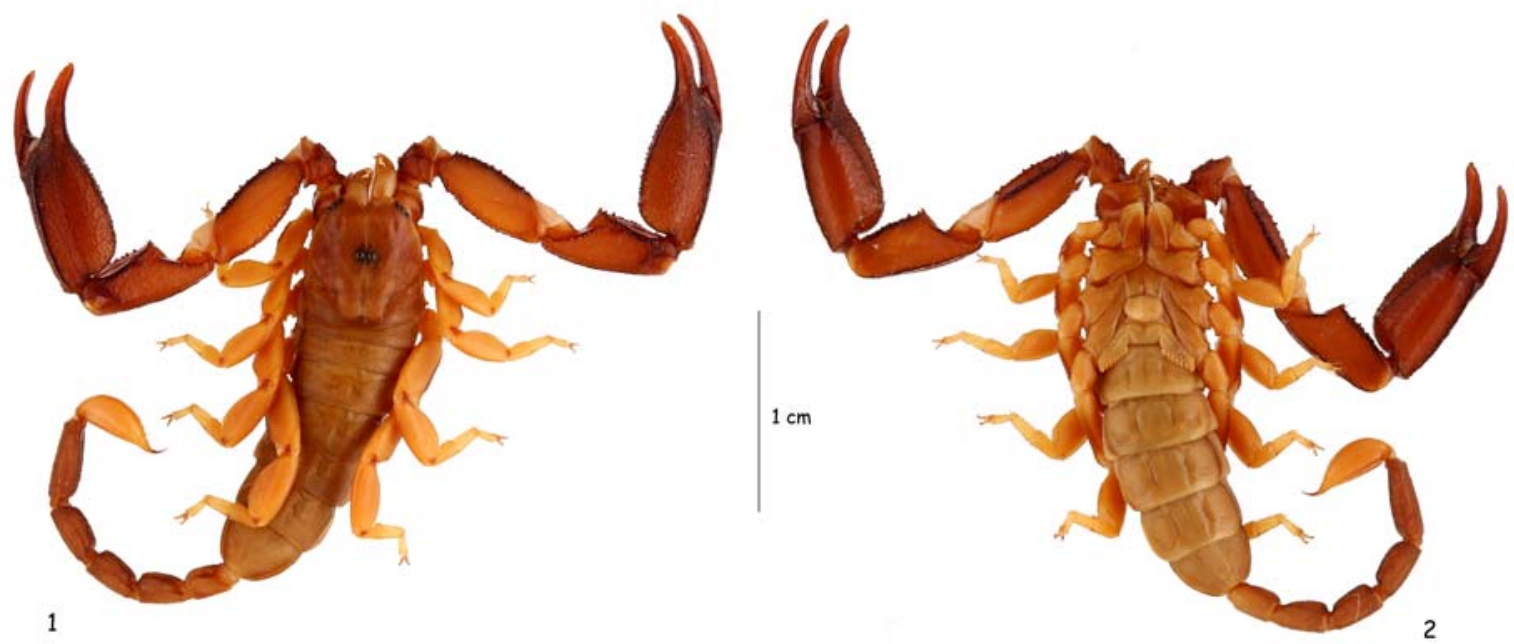

Figs 1-2. Opisthacanthus antsiranana sp.n., $\sigma^{7}$ holotype, dorsal and ventral aspects, respectively.

Рис. 1-2. Opisthacanthus antsiranana sp.n., голотип О ${ }^{\top}$, соответственно сверху и снизу.

of a Wild M5 stereo-microscope equipped with a drawing tube (camera lucida) and an ocular micrometer. Measurements follow Stahnke [1970] and are given in mm. Trichobothrial notations follow Vachon [1974] and the morphological terminology mostly follows Vachon [1952] and Hjelle [1990].

\section{The composition of the genus Opisthacan-} thus Peters, 1861

The classification given below takes into account the most recent taxonomic modifications proposed for the genus [Lourenço, 2014b]. Since most of the historical aspects concerning Malagasy species of Opisthacanthus have already been presented elsewhere [Lourenço, Goodman, 2006, 2008], they will not be further discussed here.

Family Hormuridae Laurie, 1896

Genus Opisthacanthus Peters, 1861

Subgenus Opisthacanthus Peters, 1861, with 3 species groups:

I. The cayaporum group, distributed in tropical South America.

II. The lepturus group, distributed in tropical South and Central America and on the Greater Antilles.

III. The lecomtei group, distributed in western Africa.

Subgenus Nepabellus Francke, 1974, with 5 species groups:

I. The africanus group, distributed in southern, western and eastern Africa.

II. The asper group, distributed in southern and eastern Africa.
III. The laevipes group, distributed in southern Africa

IV. The rugulosus group, distributed in southern Africa.

V. The validus group, distributed in southern Africa.

Subgenus Monodopisthacanthus Lourenço, 2001, with one species group:

I. The madagascariensis group, distributed in Madagascar, with 10 species.

Opisthacanthus madagascariensis Kraepelin, 1894

O. lucienneae Lourenço et Goodman, 2006

O. maculatus Lourenço et Goodman, 2006

O. darainensis Lourenço et Goodman, 2006

O. piceus Lourenço et Goodman, 2006

O. milloti Lourenço et Goodman, 2008

O. pauliani Lourenço et Goodman, 2008

O. andohahela Lourenço, 2014

$O$. antsiranana sp.n.

$O$. ambanja sp.n.

Opisthacanthus antsiranana sp.n.

Figs 1-12.

HOLOTYPE $\sigma^{7}$ (MNHN), Madagascar, Antsiranana Province, Montagne des Français, tropical dry forest/anthropic savannahs formation, under dry log, IX.2001, leg. W.R. Lourenço.

PARATYPES: $1 \sigma^{7}$ (MNHN), $1 \sigma^{7}$ (ZMUM Tb-549). same data as for holotype. All material was collected using ultra-violet light.

NAME: The specific name is a noun in apposition to the generic name and refers to the region where the new species was found.

DIAGNOSIS. Medium- to small-sized scorpions: 38 to $42 \mathrm{~mm}$ in total length $\left(\sigma^{7}\right)$. Coloration from pale yellow to reddish yellow, with some dark variegated zones on metasomal segments. Pectines with 7-8 teeth $\left(O^{7}\right)$; mode 7 . Hemispermatophore with distal lamina shorter and less strongly enlarged than in O. madagascariensis. $\sigma^{\top}$ genital operculum large and slightly oval 

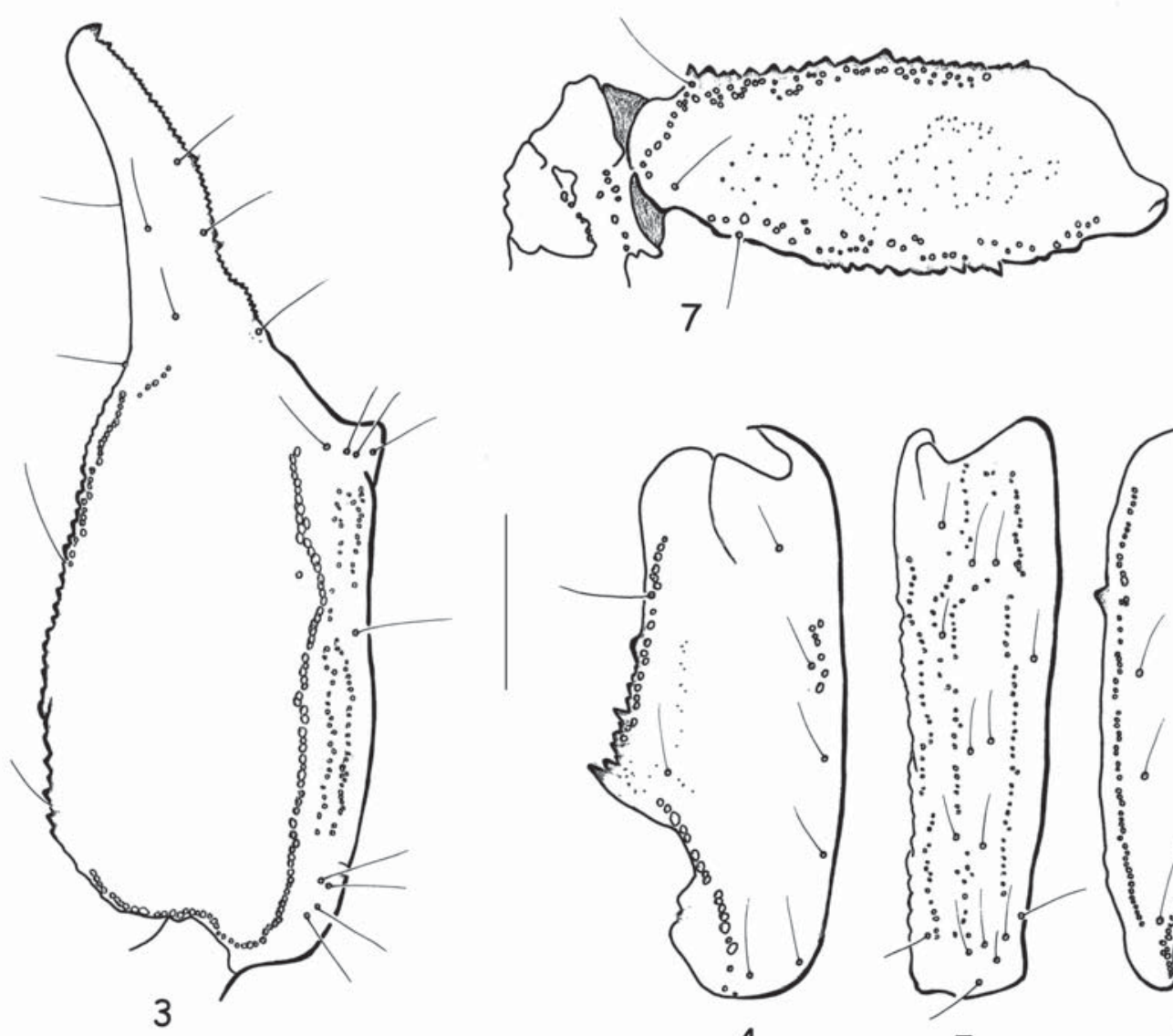

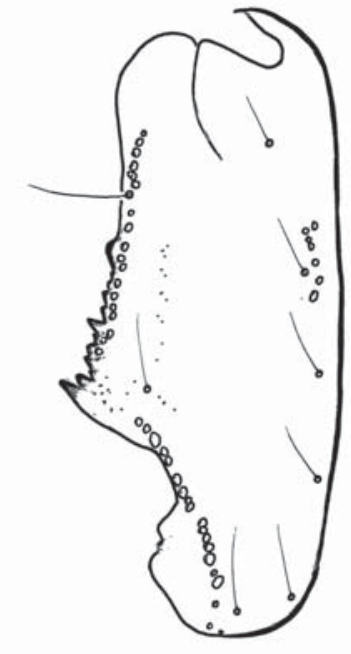

4

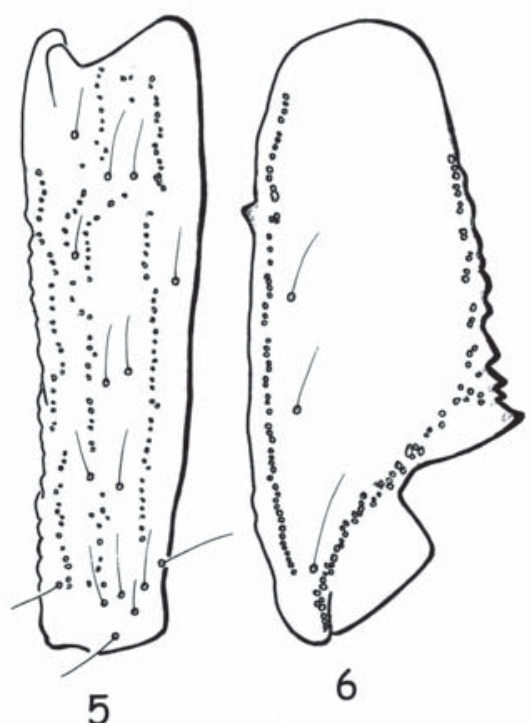

5

Figs 3-7. Opisthacanthus antsiranana sp.n., $\sigma^{7}$ holotype, trichobothrial pattern. 3 - chela, dorso-external aspect; 4-6 - patella, dorsal, external and ventral aspects, respectively; 7 - femur, dorsal aspect. Scale bar: $2.0 \mathrm{~mm}$.

Рис. 3-7. Opisthacanthus antsiranana sp.n., голотип §', характер трихоботриотаксии. 3 - хела, одновременно сверху и снаружи; 4-6 - пателла, соответственно сверху, снаружи и снизу; 7 - бедро, сверху. Масштаб: 2,0 мм.

in shape. Trichobothrial pattern of type C, orthobothriotaxy. Female unknown.

RELATIONSHIPS. The new species can be distinguished from $O$. lucienneae by the following characters: (i) distinct morphometric values, (ii) a paler coloration, (iii) granulations on carapace and metasoma less marked. In addition, both these species show a totally disjunct distribution and appear as vicariant elements.

DESCRIPTION. Based on $\sigma^{7}$ holotype and paratypes. Morphometric measurements are listed after the description.

Coloration. Basically pale yellow to reddish yellow with some dark variegated zones on metasomal segments. Carapace yellow; median and lateral eyes surrounded by black pigment. Tergites yellow to pale yellow without spots. Metasomal segments yellow, with dark intense variegated spots; vesicle pale yellow; aculeus dark reddish. Chelicerae yellow; base of fingers slightly darker; entire surface with diffuse variegated spots; fingers reddish brown with reddish teeth. Pedipalps reddish yellow; most carinae blackish. Venter and sternites yellow to pale yellow; pectines and geni- tal operculum paler than sternum and coxapophysis; legs yellowish with some internal carinae reddish.

Morphology. Carapace almost without granulations, but with punctation; smooth; furrows shallow. Anterior margin with a strong concavity reaching as far as level of $2^{\text {nd }}$ lateral eye. Median ocular tubercle flattened and lying almost in the centre of carapace; median eyes moderate, separated by one ocular diameter; three pairs of large lateral eyes. Sternum pentagonal, wider than long. Genital operculum formed by two semi-oval plates $\left(\bigcirc^{7}\right)$. Tergites with only a vestigial median carina, smooth and with punctations. Pectinal tooth count 7-7 in $\sigma^{7}$ holotype and 7-7 or 8-8 in $\sigma^{7}$ paratypes. Sternites smooth and shiny; VII acarinate, with a few punctations. Metasomal segments I to V longer than wide, with some thin and inconspicuous granulations. All carinae weakly marked in segments I-IV; segment V rounded, with some weakly marked spinoid granules on ventral surface. All segments with moderate chaetotaxy. Telson pyriform, smooth and covered with moderate chaetotaxy. Pedipalps: femur with strong and tuberculate dorsal internal, dorsal external, ventral internal and ventral 


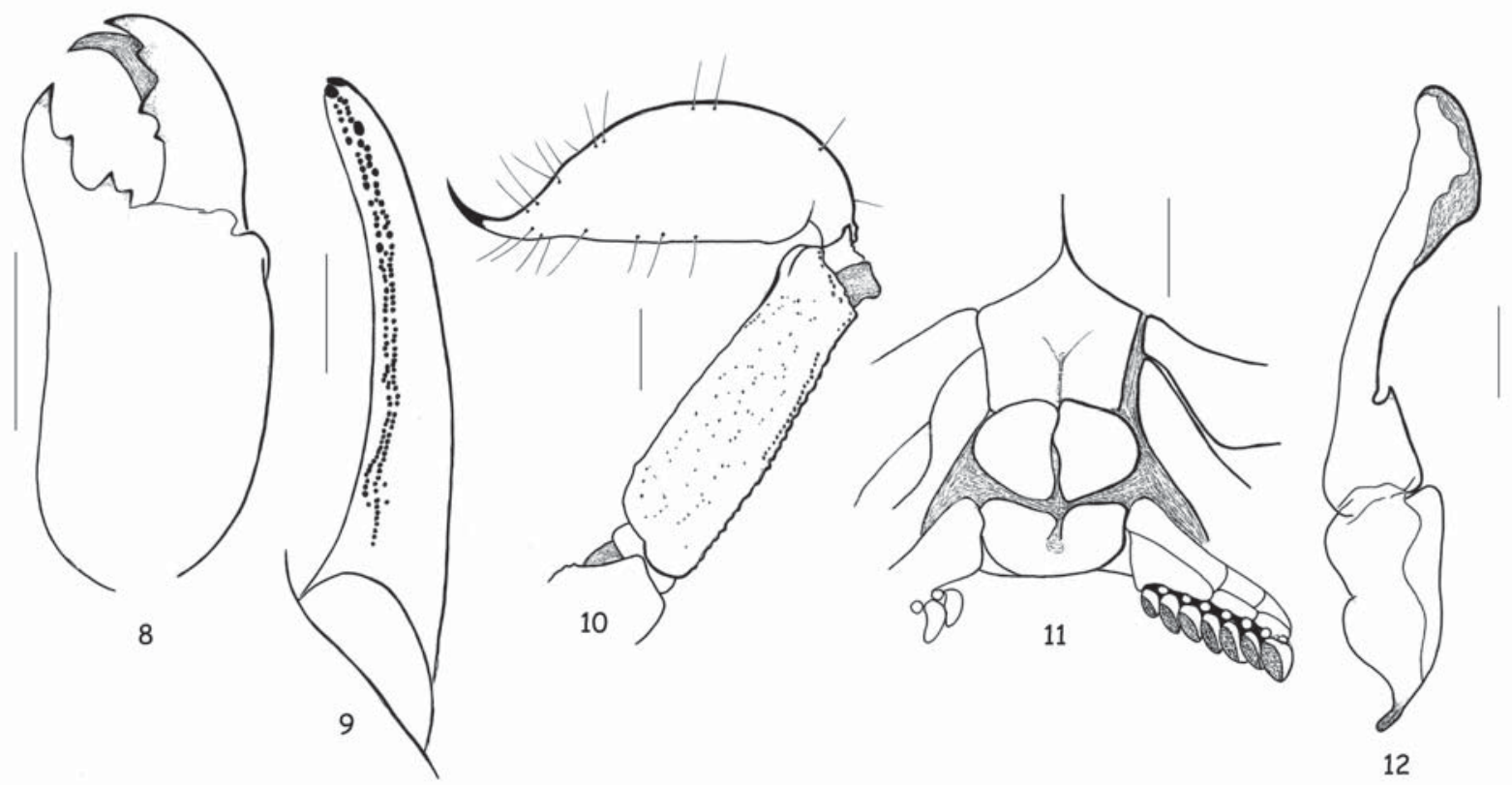

Figs 8-12. Opisthacanthus antsiranana sp.n., $0^{7}$ holotype. 8 - chelicera, dorsal aspect; 9 - cutting edge of movable chelal finger; 10 - metasomal segment $\mathrm{V}$ and telson, lateral aspect; 11 - ventral aspect, showing sternum, shape of genital operculum plates and pectines; 12 - hemispermatophore, external aspect. Scale bars $1.0 \mathrm{~mm}$.

Рис. 8-12. Opisthacanthus antsiranana sp.n., голотип О7. 8 - хелицера, сверху; 9 - режущий край подвижного пальца хелы; 10 - сегмант V метасомы и тельсон, сбоку; 11 - вид снизу, показывающий стернит, форму долей генитальной крышечки и пектин; 12 - гемисперматофор, снаружи. Масштаб 1,0 мм.

external carinae; dorsal face with very fine granulations; ventral face with a few granulations; internal face moderately to strongly granulate. Patella with internal and external faces moderately granulate; dorsal and ventral faces smooth and lustrous; dorsal internal, ventral internal, ventral external and external carinae strong; other carinae weaker. Chela moderately to strongly granular, including its internal face; dorsal marginal, external secondary, ventro-internal and ventral median carinae strong; other carinae weaker. Chelicerae typical of Scorpionoidea [Vachon, 1963]; teeth sharp. Trichobothriotaxy type C; orthobothriotaxic [Vachon, 1974]. Legs: tarsi with two lateral rows of spines, surrounded by a few long setae. Spurs moderate. Hemispermatophore as in Fig. 12, with distal lamina short and weakly enlarged.

Morphometric values (in $\mathrm{mm}$ ) of $\sigma^{\top}$ holotype. Total length (including telson) 38.7. Carapace: length 6.4; anterior width 4.1; posterior width 6.2. Mesosoma length 13.5. Metasomal segment I: length 2.2, width 1.4; II: length 2.4 , width 1.3 ; III: length 2.6 , width 1.2 ; IV: length 2.8 , width $1.2 ; \mathrm{V}$ : length 3.8 , width 1.1 , depth 1.4. Telson length 5.0. Vesicle: width 1.6, depth 1.8. Pedipalp: femur length 6.4 , width 2.6 ; patella length 6.6, width 2.9 ; chela length 11.4 , width 3.2 , depth 2.4 ; movable finger length 5.1.

\section{Opisthacanthus ambanja sp.n.} Figs 13-26.

HOLOTYPE $\sigma^{7}$ (MNHN). Madagascar, Antsiranana Province, $\mathrm{N}$ of Ambanja, road between Ambanja and Ambilobe, rainforest, under log, IX.2001, leg. W.R. Lourenço.
PARATYPES: 2 우 (MNHN), 2 우 (ZMUM Tb-548), same data as for holotype. All material was collected using ultra-violet light.

NAME: The specific name is a noun in apposition to the generic name and refers to the locality where the new species was found.

DIAGNOSIS. Medium- to small-sized scorpions: o $43.2 \mathrm{~mm}$ in total length, vs $34.1 \mathrm{~mm}$ in subadult $\%$ paratype. Coloration reddish brown to dark brown, with some blackish zones. Pectines with 6 teeth in $\sigma^{7}$ and 5-6 in 90 ; mode 6 in $\sigma^{7}$ and 90 . Hemispermatophore slender and thin; distal lamina weakly enlarged and less complex than in the other species. O genital operculum broader than long, almost oval in shape, with an incision at base. Trichobothrial pattern of type C, orthobothriotaxy.

RELATIONSHIPS. The new species can be distinguished, in particular from $O$. darainensis, by the following characters: (i) a darker overall coloration, (ii) $q$ genital operculum plate with an incision at base, (iii) hemispermatophore slender and thin, with distal lamina weakly enlarged. In addition, this new species was found in a rainforest formation while $O$. darainensis inhabits a much drier forest type.

DESCRIPTION. Based on $\sigma^{7}$ holotype and $q$ paratypes. Morphometric measurements are listed after the description.

Coloration. Basically reddish brown to dark brown with some blackish zones on pedipalp carinae. Carapace reddish brown, median and lateral eyes surrounded by black pigment. Tergites reddish brown, with posterior edges yellowish. Metasomal segments red- 

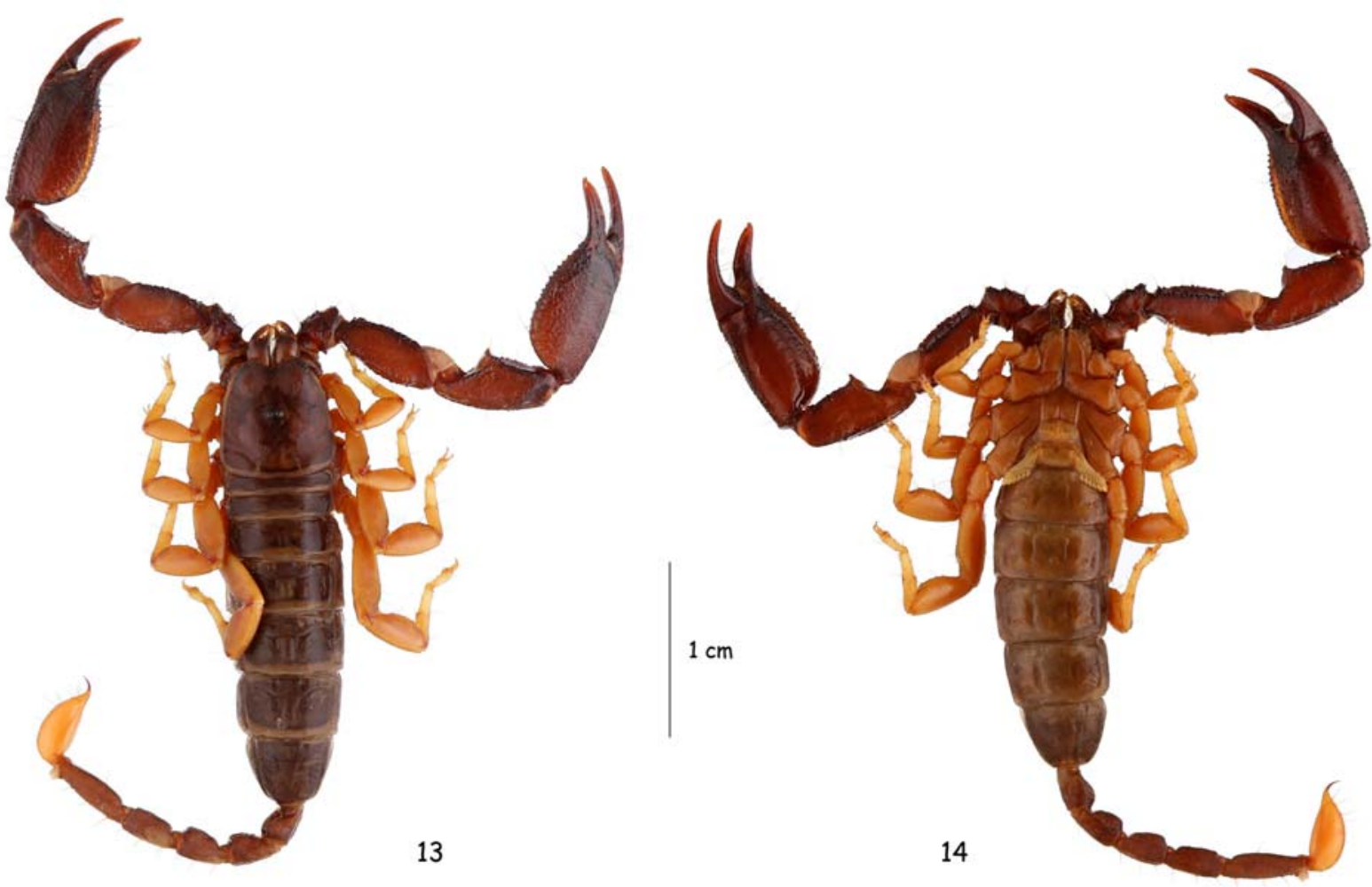

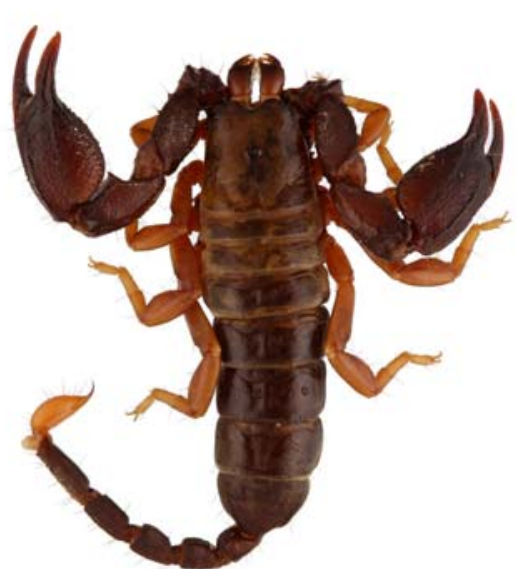

15

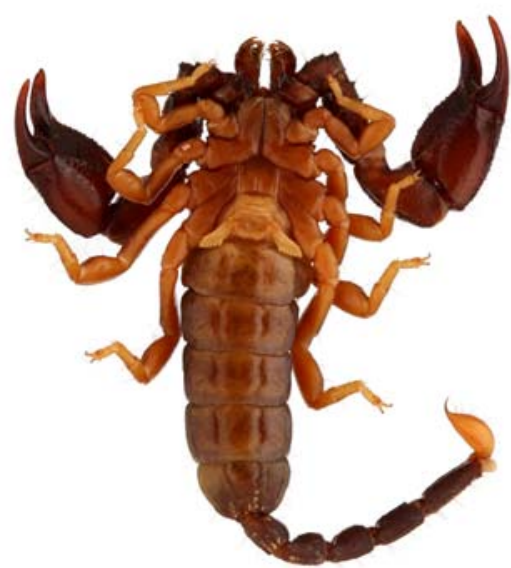

16

Figs 13-16. Opisthacanthus ambanja sp.n., $0^{\top}$ holotype and + paratype, dorsal and ventral aspects, respectively. Рис. 13-16. Opisthacanthus ambanja sp.n., голотип $O^{7}$ и паратип + , соответственнно сверху и снизу.

dish to reddish brown; vesicle yellow, with one lateral reddish band; aculeus dark reddish. Chelicerae reddish yellow to reddish brown; base of fingers blackish; entire surface with diffuse variegated dark spots; fingers blackish with reddish teeth. Pedipalps reddish brown. Venter and sternites reddish yellow; sternite
VII reddish brown; pectines and genital operculum yellow; legs yellow, with diffuse variegated dark spots in 9 우.

Morphology. Carapace smooth, with intense punctation; furrows shallow. Anterior margin with a strong concavity reaching as far as level of $2^{\text {nd }}$ lateral eye. 


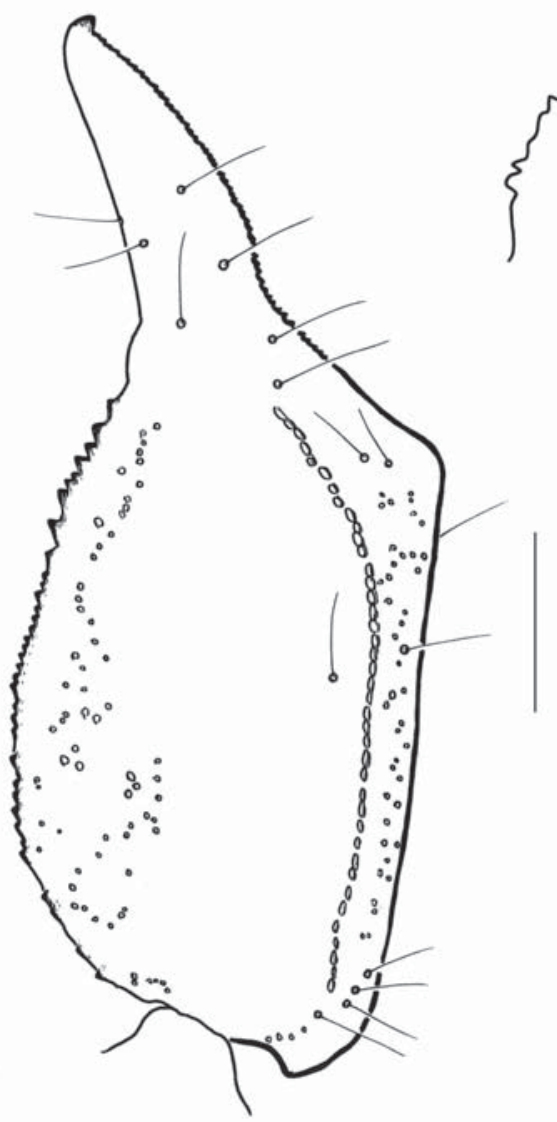

17

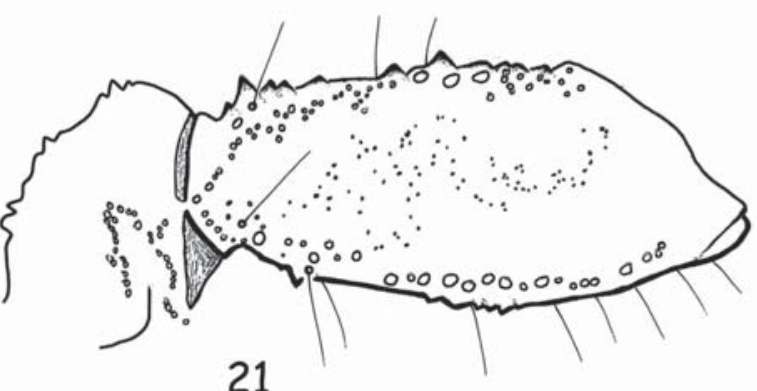

21

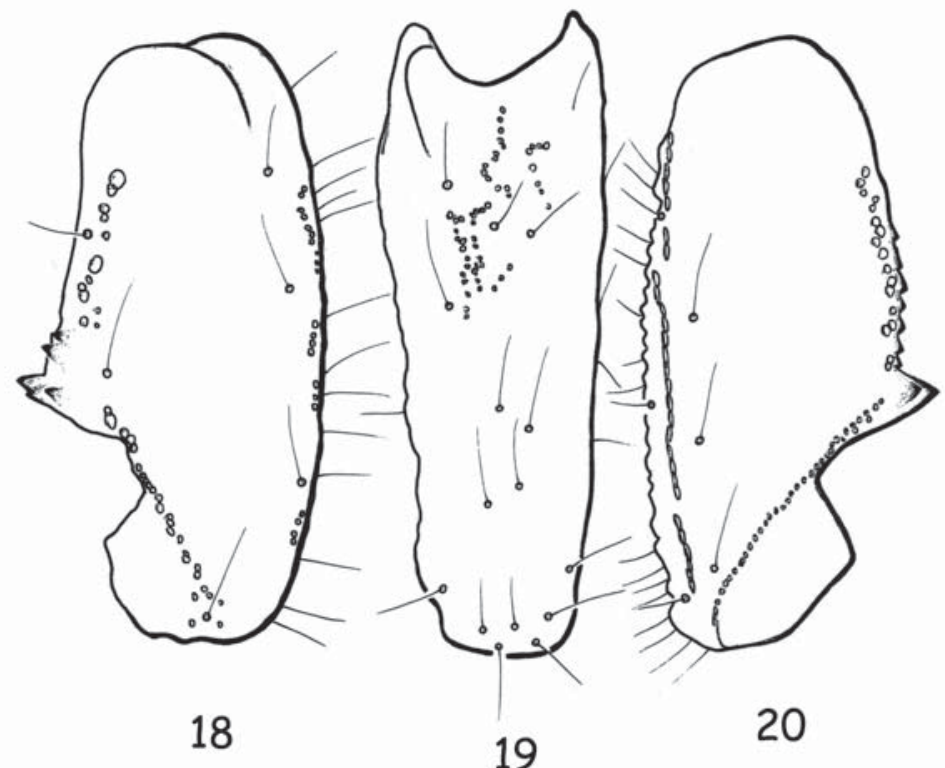

Figs 17-21. Opisthacanthus ambanja sp.n., $\bigcirc^{\top}$ holotype, trichobothrial pattern. 17 - chela, dorso-external aspect; 18-20 - patella, dorsal, external and ventral aspects, respectively; 21 - femur, dorsal aspect. Scale bar $2.0 \mathrm{~mm}$.

Рис. 17-21. Opisthacanthus ambanja sp.n., голотип $\sigma^{7}$, характер трихоботриотаксии. 17 - хела, одновременно сверху и снаружи; 18-20 - пателла, соответственно сверху, снаружи и снизу; 21 - бедро, сверху. Масштаб 2,0 мм.

Median ocular tubercle flattened and lying almost in the centre of carapace; median eyes moderate, separated by less than one ocular diameter; three pairs of large lateral eyes. Sternum pentagonal, wider than long. Genital operculum formed by two semi-oval plates $\left(\mathrm{O}^{7}\right)$ or by one single, almost oval plate $(+)$, with an incision at base. Tergites with one vestigial median carina and with intense punctation. Pectinal tooth count $6-6$ in $0^{7}$ holotype and 5-6 in + paratypes. Sternites smooth and shiny, with punctations; VII acarinate. Metasomal segments I to V longer than wide, almost smooth, except for some sparse granulations. All carinae weakly marked in segments I-IV; segment V slightly rounded with spinoid granules on latero-ventral and ventral carinae. All segments with strong chaetotaxy. Telson globular in shape, larger in $\sigma^{7}$; smooth and covered with strong chetotaxy. Pedipalps: femur with strong and tuberculate dorsal internal, dorsal external, ventral internal and ventral external carinae; dorsal face with very fine granulations; ventral face with minute granulations, almost smooth, but with punctations; internal face mod- erately granular. Patella with internal and external faces moderately granulate; dorsal and ventral faces smooth and lustrous, with punctations; dorsal internal, ventral internal, ventral external and external carinae strong; other carinae weaker. Chela strongly granular on dorso-internal and external faces; ventral face punctate; dorsal marginal, external secondary, ventro-internal and ventral median carinae moderate to strong; other carinae weaker. Chelicerae typical of Scorpionoidea [Vachon, 1963]; teeth sharp. Trichobothriotaxy type C; orthobothriotaxic [Vachon, 1974]. Legs: tarsi with two lateral rows of spines, surrounded by a few long setae. Spurs moderate. Hemispermatophore slender and thin, as in Fig. 26, with distal lamina weakly enlarged and less complex than in the other species.

Morphometric values (in $\mathrm{mm}$ ) of $\sigma^{7}$ holotype. Total length (including telson) 43.2. Carapace: length 6.4; anterior width 4.3; posterior width 6.4. Mesosoma length 16.8. Metasomal segment I: length 2.2, width 2.0; II: length 2.4 , width 1.8 ; III: length 2.6 , width 1.8 ; IV: length 3.0 , width 1.5 ; V: length 4.4 , width 1.4 , depth 

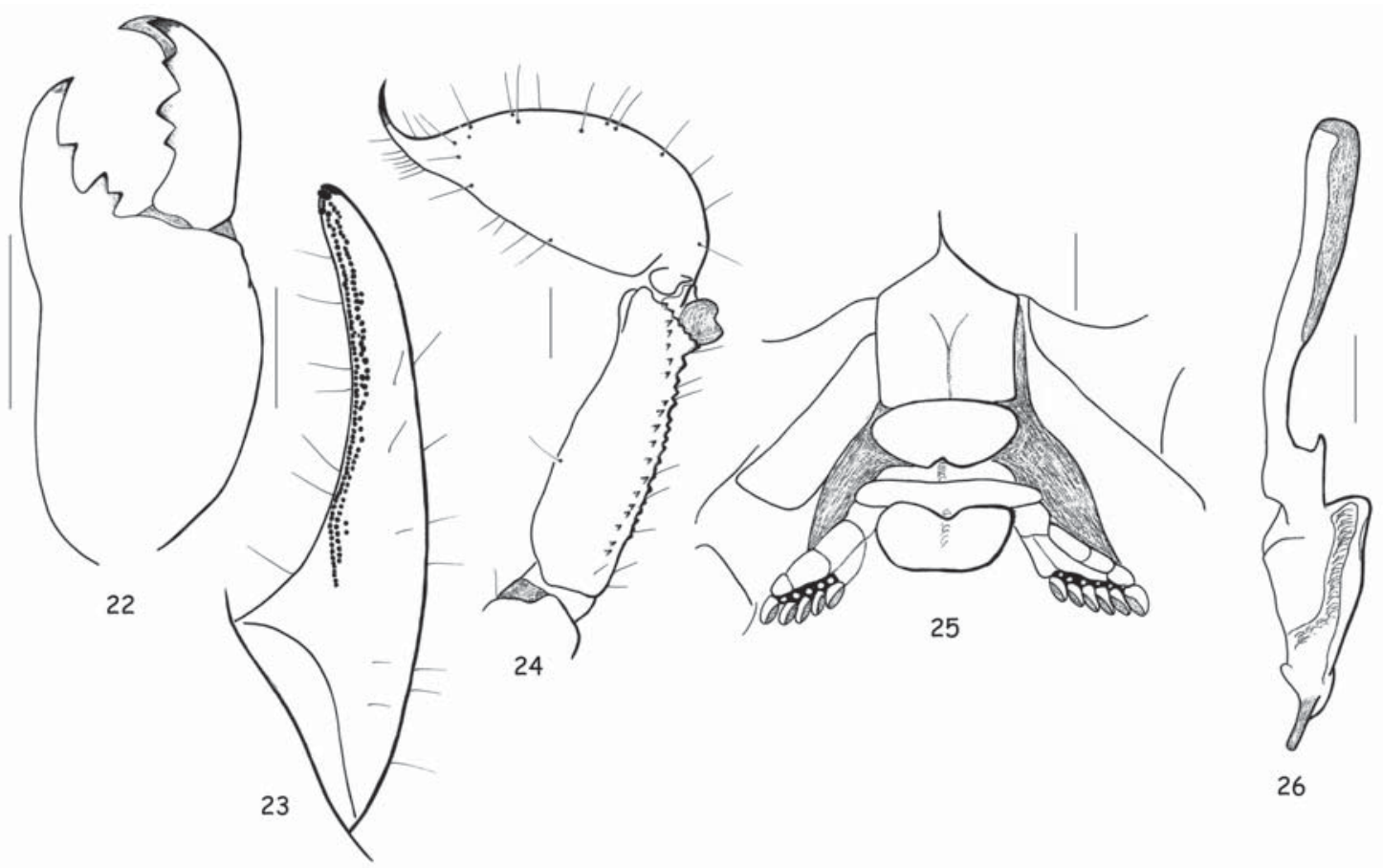

Figs 22-26. Opisthacanthus ambanja sp.n., $0^{\top}$ holotype $(22-24,26)$ and + paratype (25). 22 - chelicera, dorsal aspect; 23 - cutting edge of movable chelal finger; 24 - metasomal segment $\mathrm{V}$ and telson, lateral aspect; 25 - ventral aspect, showing sternum, shape of genital operculum plate and pectines; 26 - hemispermatophore, external aspect. Scale bars $1.0 \mathrm{~mm}$.

Рис. 22-26. Opisthacanthus ambanja sp.n., голотип О7 $(22-24,26)$ и паратип + $(25) .22$ - хелицера, сверху; 23 - режущий край подвижного пальца хелы; 24 - сегмент $\mathrm{V}$ метасомы и тельсон; 25 - вид снизу, показывающий стернит, форму долей генитальной крышечки и пектин; 26 - гемисперматофор, снаружи. Масштаб 1,0 мм.

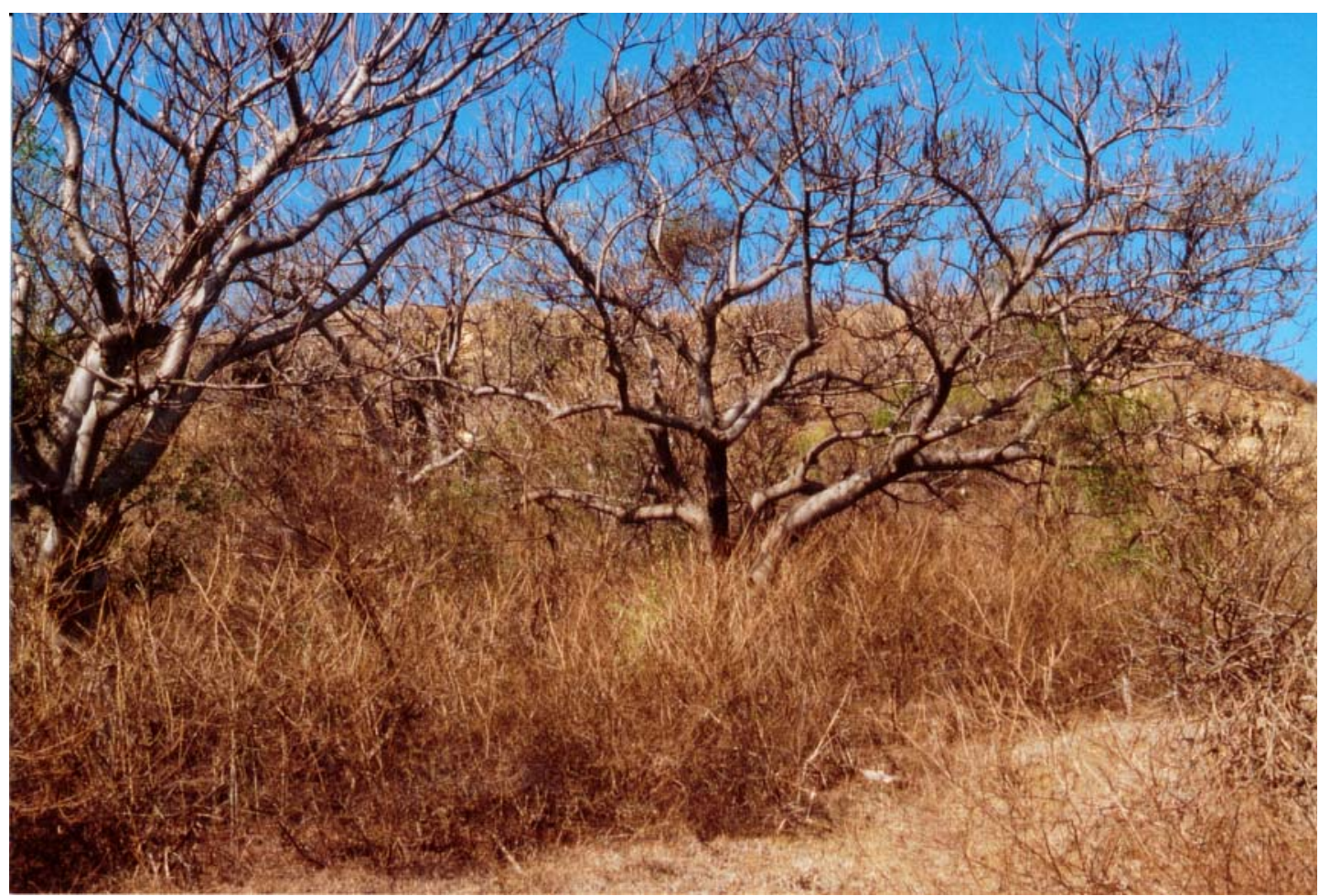

Fig. 27. Typical vegetation of the Montagne des Français region, the type locality of Opisthacanthus antsiranana sp.n.

Рис. 27. Типичная растительность в районе горы Montagne des Franзаis, типовом локалитете Opisthacanthus antsiranana sp.n. 


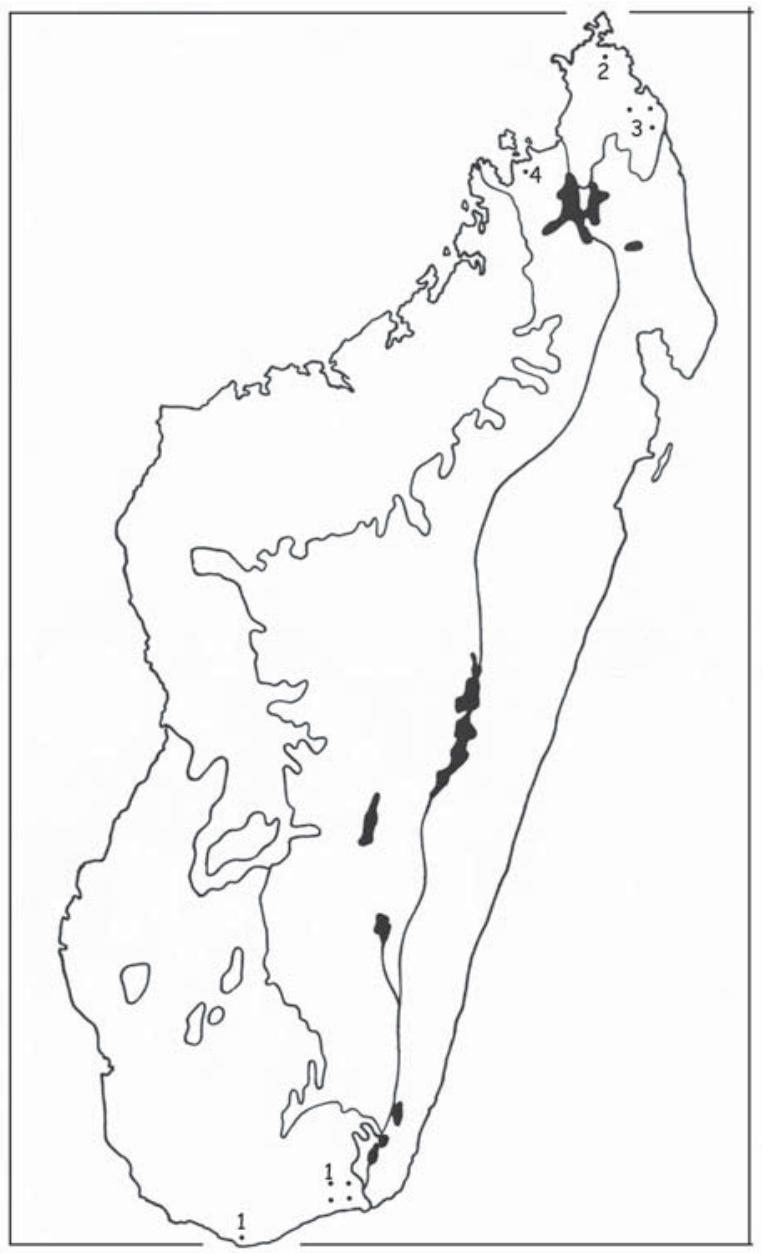

Fig. 28. Map of Madagascar with the known distributions of Opisthacanthus lucienneae (1), O. antsiranana sp.n. (2), O. darainensis (3) and $O$. ambanja sp.n. (4).

Рис. 28. Карта Мадагаскара с известными ареалами Opisthacanthus lucienneae (1), O. antsiranana sp.n. (2), O. darainensis (3) и $O$. ambanja sp.n. (4).

1.5. Telson length 5.4. Vesicle: width 2.1, depth 2.0. Pedipalp: femur length 6.4 , width 2.6 ; patella length 6.8 , width 3.4 ; chela length 11.8 , width 4.4 , depth 2.4 ; movable finger length 5.5 .

\section{Biogeographic remarks}

As recently outlined by Lourenço [2013], the general patterns of distribution observed for a given animal group largely depend on the historical factors which took place in more or less recent periods of time. The previous general idea was that environments remained stable for long time periods. That old idea has been gradually replaced by a more accurate view, based on data from ecological, palaeoclimatological and palynological studies (see Prance, 1982a). These new results clearly show that this supposed 'stability' must have been interrupted by periods of climatic change during several dry/wet/dry episodes of the late Cenozoic, especially during the Pleistocene and Holocene. During the (earlier) Quaternary, temperate regions were glaciated; while cooler, drier conditions prevailed in the tropical zones of today. These reduced the rainforest to savannas or dry forest except in regions where localized conditions of temperature and humidity allowed rainforest to persist. This historical reduction of rainforest to patchy refugia is supported by the existing biogeographical patterns of distribution and differentiation of several taxa, as well as by palynological and geomorphological evidence from many regions of the world. Several authors also postulate that the reduction of forest to small patches stimulated many changes in plant and animal populations in the refugia. These ranged from extinction to an increased rate of speciation [Van der Hammen, 1974, 1982; Prance, 1982a, b].

Scorpion biogeographical studies in tropical South America brought further evidence for the refuge theory [Lourenço, 1986, 1987, 1991, 1994, 2001]. These investigations led to the postulation of about 25 refugia, or areas of high endemism. The number, size and location of these sites correlate well with those described by other authors [Prance, 1982b], and correspond to regions of high endemism.

In the case of Madagascar, these theories have received less attention than elsewhere, as stated by Burney [1996, 1997], "There has been an understandable tendency for biogeographers working in Madagascar to focus on historical factors operating on two quite different time scales. The island's isolation represents a profound influence on a scale of millions of years. Today, however, one sees everywhere in Madagascar the consequences of factors that have operated in a much more recent time frame. What of those events influencing the biogeography of Madagascar that function on intermediate temporal scales? Specifically, what roles have Quaternary climate change and other prehuman ecological variation played in Madagascar? Studies throughout the world have demonstrated the importance of glacial-interglacial climate cycles on scales of thousands, to hundreds of thousands of years."

Biogeographers have not discussed these factors much in the context of Madagascar because so little is known about their role there. "Paleoecological research has in recent years dispelled some mysteries regarding Madagascar's past, only to reveal others. Thinking about Madagascar as a dynamic biotic phenomenon that may always be changing on several temporal scales, can have profound impact on how we interpret the island's paleobiogeography,.... what significance any observed trends of change might have for understanding the biogeographic patterns we observe today" [Burney, 1996].

The patterns of distribution observed for some Opisthacanthus populations such as $O$. lucianneae and $O$. antsiranana sp.n. in the arid formations of south-western and extreme North regions of the island, respectively, can tentatively be explained as the result of a past continuous distribution over arid formations which changed subsequently during recent Quaternary vicissitudes in a vicariance process [Bernardi, 1986]. Alterna- 
tively, the populations represented by $O$. darainensis and $O$. ambanja sp.n. in the extreme North of the island, distributed in dry and wet forest formations, respectively, clearly suggests one more case of micro-endemism in that great island [Brenon, 1972; Wilmé et al., 2006].

ACKNOWLEDGEMENTS. I am most grateful to EliseAnne Leguin (MNHN) for her assistance in the preparation of the photos and plates, and to Sergei Golovatch, Russian Academy of Sciences, Moscow for his interest in the publication of this article and his editorial help.

\section{References}

Bernardi G. 1986. La vicariance, la pseudovicariance et la convergence allopatrique // Bulletin d'Ecologie. T.17. No.3. P.145154.

Brenon P. 1972. The geology of Madagascar // Battistini R., Richard-Vindard G. (eds.). Biogeography and ecology in Madagascar. The Hague: W. Junk. P.27-86.

Burney D.A. 1996. Climate change and fire ecology as factors in the Quaternary biogeography of Madagascar // Lourenço W.R. (ed.). Biogéographie de Madagascar, Paris: Edition de l'ORSTOM. P.49-58.

Burney D.A. 1997. Theories and facts regarding Holocene environmental change before and after human colonization // Goodman S.M., Patterson B.D. (eds.). Natural change and human impact in Madagascar. // Washington: Smithsonian Institution Press. P.75-89.

Goodman S.M., Benstead J.P. (eds.). 2003. The natural history of Madagascar. Chicago: University of Chicago Press. 1709 pp.

Hjelle J.T. 1990. Anatomy and morphology // Polis G.A. (ed.). The biology of scorpions. Stanford: Stanford Univ. Press. P.9-63.

Lourenço W.R. 1986. Diversité de la faune scorpionique de la région amazonienne; centres d'endémisme; nouvel appui à la théorie des refuges forestiers du Pléistocene // Amazoniana. Bd.9. S.559-580.

Lourenço W.R. 1987. Les modèles évolutifs des Scorpions néotropicaux et la théorie des refuges forestiers du Pléistocène // Compte Rendus de la Société de Biogéographie. T.63. Fasc.3. P.75-88.

Lourenço W.R. 1991. La 'Province' biogéographique guyanaise; étude de la biodiversité et des centres d'endémisme en vue de la conservation des patrimoines génétiques // Compte Rendus de la Société de Biogéographie. T.67. P.113-131.

Lourenço W.R. 1994. Biogeographic patterns of tropical South American scorpions // Studies on Neotropical Fauna and Environment. Vol.29. No.4. P.219-231.

Lourenço W.R. 1996. Scorpions (Chelicerata, Scorpiones) // Faune de Madagascar, No. 87. Paris: Muséum national d'Histoire naturelle. $102 \mathrm{pp}$.

Lourenço W.R. 2001. Scorpion diversity in tropical South America: Implications for conservation programs // Brownell Ph. Polis G.A. (eds.). Scorpion biology and research. Oxford: Oxford Univ. Press. P.406-416.
Lourenço W.R. 2003. Scorpions // Goodman S.M., Benstead J.P. (eds.). The natural history of Madagascar. Chicago: University of Chicago Press. P.575-579.

Lourenço W.R. 2013. A new species of Grosphus Simon, 1880 (Scorpiones, Buthidae) from Central Madagascar // Entomologische Mitteilungen aus dem Zoologischen Museum Hamburg. Bd.16(189). S.57-62.

Lourenço W.R. 2014a. The genus Grosphus Simon, 1880 from south-western Madagascar, with the description of a new species (Scorpiones, Buthidae) // Zoosystema. Vol.36. P.631-645.

Lourenço W.R. 2014b. A new species of Opisthacanthus Peters, 1861 (Scorpiones: Hormuridae) from the Parc National d'Andohahela, Madagascar // Entomologische Mitteilungen aus dem Zoologischen Museum Hamburg. Bd.17(193) S.179190.

Lourenço W.R., Goodman S.M. 2006. A reappraisal of the geographical distribution of the genus Opisthacanthus Peters, 1861 (Scorpiones: Liochelidae) in Madagascar, including the description of four new species // Boletin de la Sociedad Entomológica Aragonesa. T.38. P.11-23.

Lourenço W.R., Goodman S.M. 2008. Scorpions of the Réserve Spéciale d'Ankarana, Madagascar, with particular reference to cave-dwelling animals and the description of two new species // Zoosystema. Vol.30. No.3. P.665-679.

Paulian R. 1961. La zoogéographie de Madagascar et des îles voisines // Faune de Madagascar. No.13. Paris: Muséum national d'Histoire naturelle. $484 \mathrm{pp}$.

Prance G.T. (ed.) 1982a. Biological diversification in the tropics. New York: Columbia University Press. 714 pp.

Prance G.T. 1982b. Forest refuges: Evidence from woody angiosperms // Prance G.T. (ed.). Biological diversification in the tropics. New York: Columbia Univ. Press. P.137-158.

Stahnke H.L. 1970. Scorpion nomenclature and mensuration // Entomological News. Vol.81. P.297-316.

Vachon M. 1952. Etudes sur les scorpions // Alger: Publications de l'Institut Pasteur d'Algérie, 482 pp.

Vachon M. (ed.) 1953. Contribution à l'étude du peuplement de Madagascar // Mémoire de la Société de Biogéographie. N.S. T.1. $358 \mathrm{pp}$.

Vachon M. 1963. De l'utilité, en systématique, d'une nomenclature des dents des chélicères chez les Scorpions // Bulletin du Muséum national d'Histoire naturelle, Paris. 2è sér. T.35. P.161-166.

Vachon M. 1974. Etude des caractères utilisés pour classer les familles et les genres de Scorpions (Arachnides). 1. La trichobothriotaxie en arachnologie. Sigles trichobothriaux et types de trichobothriotaxie chez les Scorpions // Bulletin du Muséum national d'Histoire naturelle, Paris. 3è sér. T.140. P.857-958.

Van der Hammen T. 1974. The Pleistocene changes of vegetation and climate in tropical South America // Journal of Biogeography. Vol.1. P.3-26.

Van der Hammen T. 1982. Paleoecology of tropical South America // Prance G.T. (ed.). Biological diversification in the tropics. New York: Columbia University Press. P.60-66.

Wilmé L., Goodman S.M., Ganzhorn J.U. 2006. Biogeographic evolution of Madagascar's microendemic biota // Science. Vol.312. P.1063-1065.

Responsible editor S.I. Golovatch 